\title{
A shepherd stirring up hope from the book of Revelation
}

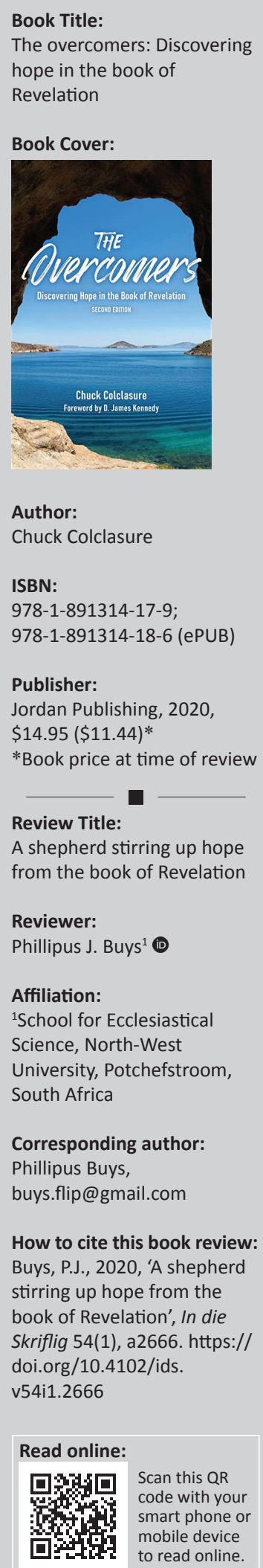

Can you understand the book of Revelation in such a way that your hope is revitalised in the world of our day and age that is filled with so much suffering, violence and fear?

In light of the coronavirus that has now spread to nearly 200 countries worldwide, having infected almost 3 million people and bringing about some three hundred thousand deaths, people are losing hope.

The way any human being lives now, your present behaviour and your character, are determined mainly by what you expect your ultimate future will be. Chris Wright said: 'Hope is hearing the music of the future, but faith is dancing to it today. And mission is acting today in the light of the future.'

The reprint of The overcomers: Discovering hope in the book of Revelation of Chuck Colclasure is a helpful reopening of the eyes of the reader and preacher to hear God's music of the future.

The author does not get stuck in the complexity of the symbolism in the book of Revelation and the controversies concerning its eschatology that people have been discouraged by.

Colclasure clearly states that his purpose with this publication is to help his readers to understand and apply the spiritual principles unveiled in the book of Revelation and to look at it devotionally and inspirationally.

The book is based on solid scholarly exegesis and where necessary, provides technical background as basis for the exposition. Yet, the explicit purpose, to help downcast believers to take heart because God rules history and will bring it to its consummation in Christ, is constantly emphasised from various angles and perspectives.

When reading the text of the book of Revelation next to this exposition, it is helpful for the reader to see the references to the chapters and verses in the margins.

It would have been helpful if an outline of the whole book of Revelation was also provided.

This book is a helpful resource to stimulate practical pastoral applications for teachers, preachers and Bible study group leaders. 